\title{
Factors Affecting Brand Equity in Batu Tourism City
}

\author{
Muhammad Afif Nadhif ${ }^{1}$, Fitri Novika Widjaja $2^{2 *} \&$ Prita Ayu \\ Kusumawardhany ${ }^{3}$
}

\author{
${ }^{1}$ University of Surabaya, Surabaya, Indonesia \\ ${ }^{2}$ University of Surabaya, Surabaya, Indonesia \\ ${ }^{3}$ University of Surabaya, Surabaya, Indonesia \\ *Corresponding author. Email: fitri@staff.ubaya.ac.id
}

\begin{abstract}
This study aims to determine the effect of Brand Awareness, Brand Image, Brand Loyalty, Perceived Brand Quality on Brand Equity in Batu Tourism City. The City of Batu has designated its area as an agropolitan tourism center in East Java. This study used qualitative research methods with data analysis in the form of SEM (Structural Equation Model) using SPSS 18.0 and AMOS 22.0 software. The sampling technique used was non-probability sampling, with a total sample of 200 respondents aged 17 years and over have visited tourist attractions in Batu city within the past year. The results of this study indicate that Brand Awareness, Brand Image, Brand Loyalty, and Perceived Brand Quality have a positive influence on Brand Equity in Batu Tourism City.
\end{abstract}

Keywords: brand awareness, band image, perceived brand quality, brand loyalty.

\section{INTRODUCTION}

The tourism sector is a prime priority and has even become a masterpiece for Indonesia in developing the country. It is also used in generating foreign exchange for the country, and currently, the tourism industry is also the core economy and can win the competition (Paath 2019). According to the travel and tourism competitiveness report, Indonesia's tourism competitiveness index rose from 42 in 2017 to 40 in 2019, while the Indonesian tourism competitiveness index was ranked fourth in 2019.

In improving the tourism sector, the President of the Republic of Indonesia, Joko Widodo, carries out various strategies, including a visa-free policy for visits, increasing the budget for promotion, and organizing a limited meeting in the tourism sector that invites business actors, Vice President, and related ministers. In addition, he also implements other strategies, like rearranging the design and infrastructures of tourism ar- eas, for example, by improving access to locations, adding certain events, for example, national and international class events, increasing human resources to support the tourism sector, and paying attention to cleanliness problems at tourism sites (Fahkri 2019).

Meanwhile, in the Covid-19 era, the President also carries out several strategies to improve the tourism sector, namely by creating a social protection program, the budget reallocation of the Ministry of Tourism and Creative Economy to support workers in the tourism sector, and giving economic stimulus for economy tourism actors (Asdhiana 2016).

One region in Indonesia that continues to develop its tourism sector is Batu, East Java. This is because Batu city has designated its area as an agropolitan tourism center, especially in East Java (Sukmana 2009 instead of Rani 2019). This has been started in 2010, where the city has its tourism development master plan and regional regulation number 
7 of 2011 concerning the 2010-2030 Batu City spatial plan. The plans administer the changes from a tourist city to a tourist center by adding many facilities on tourist objects and attractions with the support of facilities and infrastructures for visitors. By improving the tourism industry, it is expected that job vacancy and Batu city residents' income will increase, and unemployment will decrease. Not only that, according to Pertiwi (2015), Batu city is known as a city that produces fruits and vegetables and has a beautiful panorama.

According to Gartner (2014), brand awareness refers to the image of a destination that exists in the minds of potential travelers. So that brand awareness is the image of the destination in the minds of potential tourists. Brand image is "an interactive system of thoughts, opinions, feelings, visualizations, and intentions toward a destination," implying that brand image is an interactive system of thoughts, opinions, feelings, visualizations, and intentions to visit a destination (Tasci et al. 2007). Perceived brand quality is an assessment of the results of consumer evaluation of a product, not the brand quality of a product (Zeithaml 1988 instead Tasci et al. 2007). Perceived brand quality is an essential element of brand equity for companies as well as service providers (Aaker 1996, Kashif 2015, Pike et al. (2010).

According to Aaker (1991), brand loyalty refers to "the attachment that a customer has to a brand." It implies that brand loyalty is the attachment that a customer has to a particular brand. Related to destinations, brand loyalty is defined as the intention of tourists to revisit a destination and willingness to recommend destinations to others (Myagmarsuren \& Chen 2011 instead of Vinh \& Nga 2015, Pike \& Bianchi 2013). According to Aaker (1991), brand equity can be defined as "the value of a product attached to a specific name and explained its importance by noting that strong brands have strong brand equity." Brand equity is the value given to a brand associated with names and symbols that can increase or decrease the value of a product or service to consumers. Aaker (1991) states that brand equity has four main dimensions: brand awareness, perceived quality, brand association, and brand loyalty.

Rani's (2019) study aims to determine whether the variables Brand Awareness, Brand Image, Perceived Brand Quality, and Brand Loyalty affect Brand Equity in the city of Kurukshetra with 150 tourists as samples using SPPS 21 and Amos 21. The results of this study are that the Brand Awareness, Brand Image, Perceived Brand Quality, and Brand Loyalty variables have a significant influence on Kurukshetra's Brand Equity.

According to Tran et al. (2009) instead of Zeytonli 2015, the Brand Image variable has an insignificant effect on Brand Equity in Hoi An City, Vietnam. This study uses a sample of domestic tourists who have traveled to Hoi An by using the Amos 21 measurement tool.

Kashif et al. (2015) state that Brand Awareness does not have a significant effect on Brand Equity in Lahore Fort, Pakistan. This study uses a sample of 500 people who visited Lahire Fort from September to October 2015 and using the linear regression SPSS measurement tool.

This study aims to determine the positive influence between Brand Awareness, Brand Image, Perceived Brand Quality, and Brand Loyalty on the Brand Equity of Batu city.

\section{RESEARCH METHODS}

In this study, primary data collection was used to complete the research. Primary data was obtained by compiling questionnaires and conducting survey activities by distributing questionnaires that were structured and easily understood by tourists who have visited Batu city, East Java. The level and scale used were the interval level of measurement with the same distance and clear difference on the scale. The alternative answers provided for the interval level were arranged based on a numerical scale, namely the 5-point Likert Scale, which was carried out by 
providing an assessment of series of statements based on adjectives measured in a five-level scale. The sampling technique used was non-probability sampling with a purposive sampling method, namely the sampling technique. Based on considerations or judgments related to characteristics that are suitable to be sampled (Zikmund 2009). Primary data processing was obtained from research respondents using SEM (Structural Equation Models), which is a statistical model that aims to explain the relationship among several variables, Hair (2009).

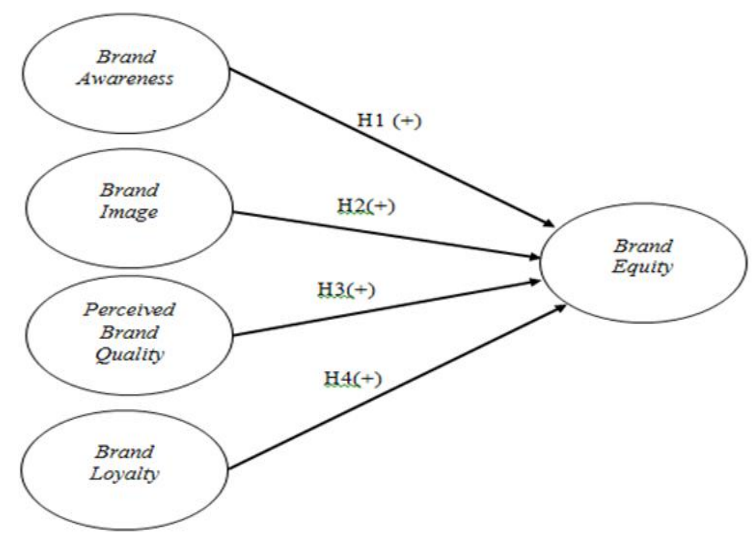

Figure 1. Research model.

The hypotheses to be tested in this study are the followings: $\mathrm{H} 1$ : Brand awareness has a positive effect on brand equity. $\mathrm{H} 2$ : Brand image has a positive on tourism brand equity. H3: Perceived brand quality has a positive effect on brand equity. H4: Brand loyalty has a positive effect on brand equity

\section{PREFERENCES, SYMBOLS AND UNITS}

200 respondents were involved in this study. The validity and reliability tests were carried out for this study. After the data was valid and reliable, then it was seen descriptively.
Table 1. Descriptive of respondents.

\begin{tabular}{|c|c|c|}
\hline Variable & uality & Percentage \\
\hline \multicolumn{3}{|l|}{ Gender: } \\
\hline Male & 128 & $64 \%$ \\
\hline Female & 72 & $36 \%$ \\
\hline \multicolumn{3}{|l|}{ Age: } \\
\hline 18-24 years old & 79 & $39 \%$ \\
\hline 25-34 years old & 25 & $12.5 \%$ \\
\hline $35-44$ years old & 31 & $15.5 \%$ \\
\hline$>45$ years old & 65 & $32.5 \%$ \\
\hline \multicolumn{3}{|l|}{ Income: } \\
\hline$\leq \mathrm{Rp} .1,800,000$ & 63 & $31.5 \%$ \\
\hline Rp.1,800,000-Rp.2,100,000 & 5 & $2.5 \%$ \\
\hline Rp.2,100,000-Rp.2,700,000 & 5 & $2.5 \%$ \\
\hline Rp.2,700,000-Rp.3,400,000 & 0 & $0 \%$ \\
\hline Rp.3,400,000-Rp.4,400,000 & 12 & $6 \%$ \\
\hline$\geq$ Rp. $4,400,000$ & 115 & $57.5 \%$ \\
\hline \multicolumn{3}{|l|}{ Profession: } \\
\hline Private employees & 31 & $15.5 \%$ \\
\hline Student & 63 & $31.5 \%$ \\
\hline Civil servants & 89 & $44.5 \%$ \\
\hline Entrepreneur & 11 & $5.5 \%$ \\
\hline Others & 6 & $3 \%$ \\
\hline \multicolumn{3}{|l|}{ Vehicle: } \\
\hline Car & 162 & $81 \%$ \\
\hline Motorcycle & 26 & $13 \%$ \\
\hline Train & 1 & $0.5 \%$ \\
\hline Public transport & 9 & $4.5 \%$ \\
\hline Others & 2 & $1 \%$ \\
\hline
\end{tabular}

Most respondents were males, aged 18-24

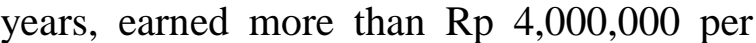
month, and work as civil servants. The most widely used vehicle was a private car.

Table 2. Mean and standard deviation of brand awareness.

\begin{tabular}{|c|c|c|c|}
\hline No & Statements & Mean & St,Dev \\
\hline BA1 & $\begin{array}{l}\text { Batu city has a good } \\
\text { name \& reputation }\end{array}$ & 3.72 & .953 \\
\hline BA2 & $\begin{array}{l}\text { The characteristic } \\
\text { of Batu city flashed } \\
\text { through my mind quickly }\end{array}$ & 3.71 & .894 \\
\hline BA3 & $\begin{array}{l}\text { The historical place } \\
\text { of Batu city are worth } \\
\text { visiting }\end{array}$ & 3.71 & .861 \\
\hline BA4 & $\begin{array}{l}\text { Batu city cultural } \\
\text { attraction are interesting }\end{array}$ & 3.76 & .952 \\
\hline BA5 & $\begin{array}{l}\text { I appreciate the attractions } \\
\text { in Batu city }\end{array}$ & 3.67 & .946 \\
\hline Total & & 3.71 & \\
\hline
\end{tabular}

Source: research data, processed. 
The variable of Brand Awareness in Batu city is perceived well by the respondents. The name of Batu city is perceived as an attractive tourist city to visit with attractive tourist attractions.

Table 3. Mean and standard deviation of brand image.

\begin{tabular}{|c|c|c|c|}
\hline No & Statements & Mean & St,Dev \\
\hline BI1 & $\begin{array}{l}\text { Visiting Batu city fits } \\
\text { my personality }\end{array}$ & 3.87 & .889 \\
\hline $\mathrm{BI} 2$ & $\begin{array}{l}\text { Visiting Batu city increases } \\
\text { my status in the eyes of my } \\
\text { friends \& relatives }\end{array}$ & 3.72 & .969 \\
\hline $\mathrm{BI} 3$ & $\begin{array}{l}\text { Batu city provides great } \\
\text { shopping facilities }\end{array}$ & 3.78 & .952 \\
\hline $\mathrm{BI} 4$ & $\begin{array}{l}\text { Natural \& fresh atmosphere } \\
\text { of Batu City is beautiful }\end{array}$ & 3.84 & .995 \\
\hline BI5 & $\begin{array}{l}\text { The atmosphere of Batu } \\
\text { city is relaxed }\end{array}$ & 3.79 & .900 \\
\hline BI6 & $\begin{array}{l}\text { Batu city weather is } \\
\text { comfortable }\end{array}$ & 3.81 & .943 \\
\hline BI7 & $\begin{array}{l}\text { Batu city maintains a high } \\
\text { level of cleanliness }\end{array}$ & 3.82 & .976 \\
\hline BI8 & $\begin{array}{l}\text { The local community } \\
\text { (tour guide) of Batu city } \\
\text { is friendly }\end{array}$ & 3.73 & .955 \\
\hline BI9 & $\begin{array}{l}\text { Batu city has good } \\
\text { transportation facilities }\end{array}$ & 3.82 & .899 \\
\hline BI10 & $\begin{array}{l}\text { Batu city is a place that has } \\
\text { more visitor-friendly } \\
\text { residents than similar places } \\
\text { nearby }\end{array}$ & 3.78 & .898 \\
\hline Total & & 3.796 & \\
\hline
\end{tabular}

Source: research data, processed.

The brand image variable is also perceived as good with a total value of 3.796 where respondents feel that Batu city fits with their personality who is happy with the beauty of Batu city, comfortable, and has good transportation. The Perceived Brand Quality variable has a mean value of 3.60, where Batu city is perceived as having quality specialties, safety, and good road quality.

The Brand Loyalty variable shows a mean value of 3.7 indicating that the respondents have the desire to return to visit Batu city and are willing to advise others to visit Batu city.
Table 4. Mean and standard deviation of perceived brand quality.

\begin{tabular}{|c|c|c|c|}
\hline No & Statements & Mean & St,Dev \\
\hline PBQ1 & $\begin{array}{l}\text { Batu city ensures a high } \\
\text { level of Personal security } \\
\text { (tourists) }\end{array}$ & 3.70 & .930 \\
\hline \multirow[t]{2}{*}{ PBQ2 } & $\begin{array}{l}\text { Batu city has high quality } \\
\text { Infrastructure (public }\end{array}$ & & \\
\hline & $\begin{array}{l}\text { facilities) } \\
\text { Batu city has good food }\end{array}$ & 3.54 & 1.120 \\
\hline PBQ3 & Quality & 3.75 & .950 \\
\hline PBQ4 & $\begin{array}{l}\text { Batu city has good road } \\
\text { quality }\end{array}$ & 3.72 & .947 \\
\hline PBQ5 & $\begin{array}{l}\text { Batu city has high quality } \\
\text { hotels }\end{array}$ & 3.62 & 945 \\
\hline Total & & 3.60 & \\
\hline \multicolumn{4}{|c|}{ Source: research data, processed. } \\
\hline \multicolumn{2}{|c|}{$\begin{array}{l}\text { Table 5. Respondent's responses } \\
\text { loyalty variable. }\end{array}$} & re & bra \\
\hline No & Statements & Mean & St,Dev \\
\hline BL1 & $\begin{array}{l}\text { Batu city provides something } \\
\text { (experiences) that is } \\
\text { interesting for everyone }\end{array}$ & 3.67 & .967 \\
\hline BL2 & I will visit Batu city again & 3.74 & .921 \\
\hline BL3 & $\begin{array}{l}\text { I would advise others to visit } \\
\text { Batu city at least once in } \\
\text { a lifetime }\end{array}$ & 3.7 & .954 \\
\hline Total & & 3.70 & \\
\hline
\end{tabular}

Source: research data, processed.

Table 6. Respondent's responses regarding brand equity variable.

\begin{tabular}{|c|c|c|c|}
\hline No & Statements & Mean & St,Dev \\
\hline BE1 & $\begin{array}{l}\text { If other cities have the same } \\
\text { advantages as Batu city, I } \\
\text { would prefer to visit Batu city }\end{array}$ & 3.79 & .954 \\
\hline BE2 & $\begin{array}{l}\text { If other city have different } \\
\text { advantages than Batu city, I } \\
\text { would prefer to visit Batu city }\end{array}$ & 3.77 & .928 \\
\hline BE3 & $\begin{array}{l}\text { If other city destinations have } \\
\text { better facilities than Batu city, } \\
\text { I prefer to visit Batu city }\end{array}$ & 3.83 & .927 \\
\hline BE4 & $\begin{array}{l}\text { Visiting Batu city gave me } \\
\text { enlightenment (pleasure) }\end{array}$ & 3.90 & .933 \\
\hline BE5 & $\begin{array}{l}\text { Batu city provides excellent } \\
\text { Opportunities for recreational } \\
\text { activities }\end{array}$ & 3.78 & .903 \\
\hline Total & & 3.8 & \\
\hline
\end{tabular}

Source: research data, processed.

The mean value of the Brand Equity variable shows 3.8, where respondents feel that visiting Batu city can please them because of the facilities and fun recreational activities 
compared to other cities.

Table 7. AVE and CR variable.

\begin{tabular}{llcc}
\hline No & Variable & $\begin{array}{l}\text { Construct } \\
\text { Reliability }\end{array}$ & AVE \\
\hline 1 & brand awareness & 0.861 & 0.554 \\
2 & brand image & 0.875 & 0.415 \\
3 & perceived brand & & \\
& quality & 0.814 & 0.474 \\
4 & brand loyalty & 0.827 & 0.617 \\
5 & brand equity & 0.864 & 0.565 \\
\hline
\end{tabular}

Source: research data, processed.

Table 8. Structural modal goodness-of-fit results.

\begin{tabular}{lllll}
\hline No & Fit test & $\begin{array}{l}\text { match } \\
\text { criteria }\end{array}$ & result & desciption \\
\hline 1 & C min/DF & $\leq 3.00$ & 1.934 & good fit \\
2 & RMSEA & $\leq 0.08$ & 0.69 & good fit \\
3 & GFI & $\geq 0.90$ & 0.819 & marginal fit \\
4 & TLI & $\geq 0.90$ & 0.872 & marginal fit \\
5 & CFI & $\geq 0.90$ & 0.885 & marginal fit \\
\hline
\end{tabular}

Source: research data, processed.

The results of the structural model test show that $\mathrm{C}$ min/DF and RMSEA results are good fit, while GFI, TLI, and CFI have marginal fit results.

Table 9. Summary of hypothesis testing results.

\begin{tabular}{lllll}
\hline $\begin{array}{l}\text { Hypo- } \\
\text { thesis }\end{array}$ & $\begin{array}{l}\text { The } \\
\text { Relationship } \\
\text { between } \\
\text { constucts }\end{array}$ & $\begin{array}{l}\text { Estimate } \\
\text { values }\end{array}$ & $\begin{array}{l}\text { Critical } \\
\text { ratio }\end{array}$ & P-value \\
\hline $\mathrm{H} 1 \quad \begin{array}{l}\text { brand awareness } \\
>\text { brand equity }\end{array}$ & 0.195 & 2.658 & .008 \\
$\mathrm{H} 2$ & $\begin{array}{l}\text { brand image } \\
\text { > brand equity }\end{array}$ & 0.285 & 2.934 & .003 \\
$\mathrm{H} 3 \quad \begin{array}{l}\text { perceive brand } \\
\text { quality > brand } \\
\text { quality }\end{array}$ & 0.311 & 3.089 & .002 \\
$\mathrm{H} 4 \quad \begin{array}{l}\text { brand loyalty }> \\
\text { brand equity }\end{array}$ & 0.231 & 3.115 & .002 \\
\hline
\end{tabular}

Based on the summary in Table 9, it could be seen that the $\mathrm{H} 1$ shows a significant result. This shows that the Brand Awareness of Batu city has a positive influence on Brand Equity, with the magnitude of the influence of 0.195. Hương et al. (2015) explain that Brand Equity is an important variable of consumer Brand Awareness. Gartner (2014) examines that the dimensions of
Brand Awareness and Brand Equity have a strong relationship in a destination. Zeytonli et al. (2015) suggest Brand Equity in sports tourism destinations related to Brand Awareness, Brand Image, Perceived Quality, and Brand Loyalty.

$\mathrm{H} 2$ also shows the same results with an estimated value of 0.285 with a P-value of 0.003. The results of this test show that Brand Image can influence the Brand Equity of Batu City. These results are supported by the results of the main journal by Rani (2019) which states that Brand Image has a positive effect on Brand Equity in Batu tourism city. Batu city itself is one of the tourist cities in Indonesia with various kinds of extraordinary tourism potential. This is also supported by the success of the Batu city government that won many awards, and one of them was Indonesia's Attractiveness Awards 2019. Therefore, awards and all existing tourism potential could create a positive image for Batu city so that the community would also increase its interests to visit Batu city.

The results of $\mathrm{H} 3$ testing show the variable Perceived Brand Quality has a positive effect on Brand Equity with a value of Construct Reliability (C.R.) amounting to 3.089 and the standard estimate value of 0.311 . These results are in accordance with Perceived Brand Quality as an essential element of a tourism brand for service providers (Aaker 1996). In the context of tourism, Konecnik \& Gartner (2007) state that the Brand Quality of a tourism destination is an essential and strong dimension of Brand Equity. Vinh \& Nga (2015) conclude that brand quality is an objective and goal of brand loyalty in positively influencing each other. These results are in accordance with the results of Rani's (2019) research, which state that brand loyalty has a positive effect on brand equity.

The results of $\mathrm{H} 4$ testing show that the variable Brand Loyalty has a positive effect on Brand Equity with a value of C.R. of 3.115 and the standard estimate value of 0.231 . Previous research on a destination (Kashif et al. 2015) shows that loyalty to a 
destination positively affects overall destination equity. These results are supported by the results of Rani's (2019) research, which state that Brand Loyalty positively affects Brand Equity in Batu. Data in 2019 stated that tourist visits in Batu city reached 7.2 million tourists and decreased in 2020 due to the Covid-19 pandemic. Head of the Batu City Tourism Office, Arief As Siddiq, targets 2 to 3 million tourists by the end of 2020; in fact, when the new normal period lasted until October, the visit reached 1.5 million and was still increasing. From these facts, it could be seen that the interest of local and foreign tourists is increasing as proven by an increase in the number of visitors. This could be seen that visitors' loyalty to Batu tourism city looks relatively high, affecting the Brand Equity of Batu tourism city.

\section{CONCLUSION}

This study concludes that from the four hypotheses that had been tested using Structural Equation Model (SEM) analysis with AMOS software, the results of all the hypotheses show a positive influence. The further explanation is as follows: a) Brand Awareness of Batu city has a positive influence on Brand Equity, b) Brand Image is able to influence the Brand Equity of Batu city positively, c) Perceived brand quality has a positive effect on Brand Equity, d) Brand loyalty has a positive effect on Brand Equity.

Recommendations from the results of this study were based on the value of the most significant influence, perceived brand quality, which have a positive effect on brand equity so that the Batu City government should be able to improve infrastructures such as road conditions to very crowded tourist attractions, especially during weekends or holidays. Tourists are more comfortable with existing public facilities to meet the needs of tourists while visiting Batu city. Meanwhile, further research could be carried out in other tourism cities in Indonesia.

\section{REFERENCES}

Aaker, D.A. 1991. Managing Brand Equity. New York: Free Press.

Aaker, D.A. 1996. Building Strong Brands. New York: Free Press.

Asdhiana, M. 2016. Gebrakan presiden Jokowi gairahkan sektor pariwisata. Retrieved from: https://travel.kompas.com/read/2016/05/28/20160 0127/Gebrakan.Presiden.Jokowi.Gairahkan.Sekto r.Pariwisata?page=all.

Fakhri, F. 2019. Ini arahan presiden Jokowi untuk pengembangan pariwisata. Retrieved from: https://nasional.okezone.com/read/2019/11/21/33 7/2132722/ini-arahan-presiden-jokowi-untukpengembangan-pariwisata.

Gartner, W.C. 2014. Brand equity in a tourism destination. Journal Place Branding and Public Diplomacy 10(2): 108-116.

Hair Jr., J.F. 2009. Multivariate Data Analysis. $7^{\text {th }}$.ed. New York: Pearson Prentice Hall.

Hương, H.T.T. Dản, D.X. \& Trang, N.T.Q. 2015. Measuring the relationship between behavioral intention and customer-based Brand equity by using the structural equation model (SEM). Journal of Science: Economics and Business 31(2): 15-25.

Kashif, M. Samsi, S.Z.M. \& Sarifuddin, S. 2015. Brand equity of Lahore fort as a tourism destination brand. Revista de Administracao de Empresas 55(4): 432-443.

Konecnik, M. \& Gartner, W.C. 2007. Customerbased brand equity for a destination. Annals of Tourism Research 34(2): 400-421.

Paath, C.K.Y. 2019. Pariwisata jadi sektor prioritas unggulan pemerintahan Jokowi. Retrieved from https://www.beritasatu.com/gayahidup/580280/pariwisata-jadi-sektor-prioritasunggulan-pemerintahan-jokowi.

Pertiwi, A. 2015. 6 pesona wisata kota Batu yang wajib dikunjungi. Retrieved from: https://ravel.kompas.com/read/2015/06/16/11300 0527/6.Pesona.Wisata.Kota.Batu.yang.Wajib.Dik unjungi? page $=$ all.

Pike, S. Bianchi, C. Kerr, G. \& Patti, C. 2010. Consumer-based Brand equity for Australia as a longhaul tourism destination in an emerging market. International Marketing Review 27(4): 434-449.

Pike, S. \& Bianchi, C. 2013. Destination Brand equity for Australia: testing a model of CBBE in short haul and long-haul markets. Journal of Hospitality and Tourism Research 20(10): 1-21.

Rani. 2019. Customer-based brand equity index of Kurukshetra. Journal of Tourism Analysis 26(1): 46-61.

Tasci, A.D.A. Gartner, W.C. \& Cavusgil, S.T. 2007. Measurement of destination Brand bias using a quasi-experimental design. Tourism Management 28(6): 1529-1540. 
Vinh, T.T. \& Nga, V.T.Q. 2015. The relationship between components of customer-based Brand equity for destination: conceptual framework and preliminary testing for scales. South East Asia Journal of Contemporary Business, Economics and Law 7(2): 47-53.

Zikmund, W.G. Babin, B.J. Carr, J.C. \& Griffin, M. 2009. Business Research Methods. $8^{\text {th }}$ edition. USA: South-Western College Publishing.

Zeytonli, A.H. Madadi, B. \& Dana, A. 2015. The customer-based Brand equity for sport tourism destinations. Research Journal of Sport Sciences 3(1): $1-7$. 